\title{
Theology chronicle - Opening words at the graduation cere- mony at the University of Pretoria (Part 4 - Law, Theology \& Veterinary Sciences) 27 March 2001
}

J D Sinclair

(Vice-Principal, University of Pretoria)

The mission of the University of Pretoria, to be an internationally competitive and locally relevant, comprehensive research institution is by now deeply entrenched in the minds of all its stakeholders. This mission, to which we remain steadfastly committed, will ensure that the qualifications obtained by students at this University will serve them well in the development of their future careers. Through our efforts to steer a strong and sound vessel safely through the turbulent waters that characterise the higher education sector, we are able to say, with confidence, to all of you, that you can and should be proud to become a Tukkies graduate.

The Minister of Education recently released the new National Plan for Higher Education. There are some important matters contained in the Plan, which sets out the framework for the future of the tertiary sector. I cannot do justice to all aspects of the Plan, but I should like to share with you a few of the possible implications of the Plan, and its relevance for this University.

Die Nasionale Plan is gebaseer op die "Education White Paper" van 1997, en dien ook as die Staat se antwoord op die verslag van dic Raad op Hoër Onderwys wat verlede jaar uitgereik is. Daardie verslag het verskeic reaksies ontlok, spesifiek oor die kategorisering van hoër onderwys instellings in "bedrock, multi-purpose, and comprehensive research institutions". Hierdie universiteit het met die verskyning van die verslag in Juniemaand verlede jaar onmiddellik bevestig dat dit aan al die vereistes van ' $n$ "comprehensive research institution" voldoen. Kriteria soos die persentasie nagraadse inskrywings, navorsingsuitsette, die aantal dosente met doktorale grade, en die feit dat UP die volle spektrum van tersiêre kwalifikasies aanbied, het, altesaam, geen twyfel gelaat dat ons binne die top kategorie van universiteite val nie. Ons het dus met groot verwagtinge na die reaksie van die Minister op die Raad se aanbevelings uitgesien.

Dic kommentaar wat ontvang is oor die Raad op Hoër Onderwys se kategorisering was in die algemeen negaticf. Dit het vir baie mense aangedui dat die sogenoemde historiese benadeelde universiteite in die kategorie "bcdrock" sou val, en dat 'n rigiede, hiërargiese wyse om instellings te differensieer 'n negaticwe impak op die hele stelsel sou 
bewerkstellig. In die huidige nasionale plan, dus, het die kategorisering verdwyn, of ten minste het die woorde van kategorisering verdwyn. Maar die feit bly staan dat daar wel sommige universiteite is wat goed geposisioneer is om ten volle as nagraads- en navorsingsinstellings die sektor te dien, terwyl daar ander is wat tot 'n groter mate op voorgraadse onderrig sal moet konsentreer. Daar is geen twyfel nic dat die minister se verwagtinge van UP is om voort te gaan om Suid- $A$ frika se top graduandi aan die mark te lewer, en om deur uitnemende navorsing ' $n$ groot bydrae te maak aan die sosiale en ekonomiese ontwikkeling van ons land.

The National Plan identifies several key features of the higher education sector that require attention. First, it considers that the participation rate of 20-24 year olds in the sector is too low, and should increase from $15 \%$ to $20 \%$. It also expects universities to provide more opportunities for mature, part-time, and especially female students. It states, in no uncertain terms, that the proportion of black students is too low at universities like UP. And it sets out benchmarks for graduation throughput at all levels, because of its concern that too many students who enroll at university drop out without attaining their degree.

The plan acknowledges, however, that the poor success rates in the matriculation examinations, and the paucity of matriculants who obtain university exemption and passes in mathematics on the higher grade, will make it difficult for universities to achieve the goals it sets forth. It therefore accepts that in the next five years the main challenge will be to improve efficiency and quality within the sector by the improvement of graduation rates and a stronger focus on research.

A very important aspect of the plan is its aspiration, via financial incentives and penalties, that will be built into a new state subsidy formula, to alter the balance of student enrolments between the humanities, business and commerce, and science, engineering and technology. It expects the humanities proportion of enrolled students to drop from $49 \%$ to $40 \%$, while it expects enrolments in business and commerce to increase from $26 \%$ to $30 \%$, and enrolments in Science, Engineering and Technology (SET) to increase from $25 \%$ to $30 \%$.

There is no universal agreement either on the likely impact of this announcement on the human and social sciences, or on its wisdom for the welfare of the country.

I must offer some comment for your consideration on both of these issues. I do so because of the importance of the implications for the Faculties of Law and Theology. I beg indulgence from the veterinary fratemity - the topic is also important for them as South Africans, rather than in their capacity as scientists.

If it were realistically possible to increase participation rates, the number of students enrolled at universities would increase. A shift 
downwards in the proportions currently studying the humanities proper and the social sciences could therefore nevertheless be expected to permit the total enrolments in these fields to remain fairly constant. But the truth is, and the plan acknowledges it, that student enrolments have been declining.

Higher participation rates, the plan states, are unlikely to be achieved before the elapse of ten to fifteen years. The shift in proportions between the disciplines, however, is scheduled to take place over the next five to ten years. Inexorably, it seems to me, there is a real possibility that shrinkage in student enrolments in the human and social sciences, including for this purpose Law and Theology, could occur.

Smaller student numbers usually go hand in hand with cuts in resources, fewer academic staff, a resultant drop in research output in thesc areas, and a smaller pool of postgraduate students to replace retiring professors, and to take the lead in the preservation and advancement of these disciplines. No one is saying that these things will not be allowed to occur, and I therefore take it to be the case that these propositions are not regarded as problematic, at least in the national debate at this time.

Devclopments like these would in my view be undesirable for South Africa, and I believe, singularly bad for the University of Pretoria. I have no doubt that South Africa needs to build its human resource capacity in SET and in business and management skills. And I wholeheartedly support all efforts to do so. My one worry is that it seems to be going as an unargued case, that the advancement of these areas will be at the cost of the humanities and social sciences. I am deeply puzzled by this approach, because the National Plan actually quotes from the Report of the Council on Higher Education in emphasizing the importance to our young and fragile democracy of the human and social sciences:

"Higher Education... has immense potential to contribute to the consolidation of democracy and social justice, and to the growth and development of the economy. These contributions are complementary. The enhancement of democracy lays the basis for greater participation in economic and social life... Higher levels of employment contribute to political and social stability and the capacity of citizens to exercise and enforce democratic rights and participate effectively in decision-making. The overall well being of nations is vitally dependent on the contribution of higher education to the social, cultural, political and economic (and I would add moral) development of its citizens" (CHE 25-6). 
Our country has come through several years of immense social and political upheaval. We are extremely fortunate to have had the benefit of leadership that helped us to avoid the bloodshed and revolution that besets so many countries in Africa, in the Middle-East, and in Eastern Europe. Our people have been spared the ultimate trauma of full-scale war. But they have not gone unscathed.

As we struggle to come to terms with a tortured past, as we look ahead to a sound future in the global village, at the same time we experience the fallout of major social and political change. Criminals roam free, forcing law-abiding citizens to take shelter behind high walls to avoid being hijacked and/or shot. The public, in large measure black people, experience so much unchecked violence perpetrated on their children, their wives and their families, that they resort to vigilantism, take the law into their own hands and publicly try and execute suspected criminals. Family murders and suicides feature virtually daily in our news. They are the extreme manifestations of wider societal distress. Redistribution of wealth by robbery and corruption ruin our capacity to build a functioning society of which we can be proud. Large numbers of our newly qualified professionals, black and white, from lawyers through accountants, to nurses, too many of the kinds of young people here tonight, seek to emigrate for a better life.

I should like to put it to you that we need the humanities and the social sciences more than we have ever needed them before. We neglect their advancement and nurturing at our peril. The wellness of our society, the healing of the terrible wounds that we have inflicted upon one another, depend on a strong pool of professional social scientists and a powerful group of intellectuals who can display the qualities of true leadership, born of a deep understanding of the workings of a good civil society. We need lawyers to guide the entrenchment of a culture of tolerance and human rights. We need theologians to guide our moral development and to give us the faith to sustain and endure the vicissitudes of life. I am confident that we need them and other social scientists as badly as we need natural scientists, engineers and technology experts, and skilled business people and managers. My case is that the scientists and engineers and managers cannot thrive in a society that is dysfunctional. And ours is dysfunctional.

I conclude with two special pleas. First, let us not, at the University of Pretoria, permit the downgrading of the humanities and social sciences in order to advance the disciplines currently thought almost uniquely crucial for our prosperity. Secondly, I urge those of you who have been privileged to obtain a qualification of which you can be proud, from an institution that is determined to play its part in building our society and our country, to remain strong and brave and true, through 
good times and bad. We need your skills and we need your commitment. In celebrating your achievements, make your own commitment to your disciplinc known. Do your best to heal and help our society through your newly acquired knowledge and understanding.

Ek wil terselfdertyd aan elke individu wat ' $n$ rol gespeel het in die bcreiking van die doelwitte van die studente wat vanaand hier 'n kwalifikasie verwerf, my opregte dank betuig vir u waardevolle insette, ondersteuning en belangstelling. U bydrae gaan nie ongesiens verby nie en verdien die nodige erkenning. Namens die Universiteit sê ek baie dankie. 